\title{
Hydroxyl radical generation by rheumatoid blood and knee joint synovial fluid
}

\author{
Harparkash Kaur, Sally E Edmonds, David R Blake, Barry Halliwell
}

\begin{abstract}
Objective-To demonstrate directly that highly reactive hydroxyl radicals (OH') can be generated in patients with rheumatoid arthritis and contribute to joint damage, and to examine the ability of blood to cause $\mathrm{OH}^{\prime}$ generation.
\end{abstract}

Methods-The sensitive and specific technique of hydroxylation of aromatic compounds (salicylate and phenylalanine) was used to measure OH:. Synovial fluid and blood from patients with active rheumatoid arthritis were aspirated and immediately added to tubes containing salicylate and phenylalanine as detectors of $\mathrm{OH}^{\circ}$, or to tubes containing saline as a control. Levels of specific products of attack of $\mathrm{OH}^{\circ}$ upon salicylate (2,3- and 2,5-dihydroxybenzoates) and phenylalanine (ortho- and meta-tyrosines) were measured by high performance liquid chromatography.

Results-Synovial fluid samples aspirated into saline never contained ortho- or meta-tyrosines or 2,3-dihydroxybenzoate. Of 53 patients examined, synovial fluid and blood from 36 caused formation of ortho- and meta-tyrosines when aspirated into solutions containing phenylalanine. Repeated sampling from three "positive" patients showed consistent evidence of these hydroxylation products. Similarly, of 22 patients examined, synovial fluid and blood from 18 caused formation of 2,3and 2,5- dihydroxybenzoates when aspirated into salicylate solutions. Further evidence for the role of $\mathrm{OH}^{*}$ was provided by inhibition of the hydroxylation by the specific $\mathrm{OH}^{*}$ scavengers mannitol and sodium formate.

Conclusions-Aspirated knee joint fluids and blood from rheumatoid arthritis patients can generate $\mathrm{OH}^{\circ}$, consistent with current views on the importance of this radical as a cytotoxic agent in rheumatoid disease. The ability of body fluids to cause $\mathrm{OH}^{\circ}$ formation is not correlated with simple laboratory indices of disease activity, but is reproducible on sequential sampling from the same patients. The mechanism and significance of the phenomenon in rheumatoid arthritis pathology remain to be established.

(Ann Rheum Dis 1996;55:915-920)

There is substantial indirect evidence to support the current view that reactive oxygen species (ROS) such as superoxide radical $\mathrm{O}_{2}{ }^{\circ}$, hydrogen peroxide $\left(\mathrm{H}_{2} \mathrm{O}_{2}\right)$, hydroxyl radical $\left(\mathrm{OH}^{\circ}\right)$, and hypochlorous acid $(\mathrm{HOCl})$, as well as reactive nitrogen species (RNS) such as nitric oxide $\left(\mathrm{NO}^{\circ}\right)$ and peroxynitrite (ONOO$)^{-}$, contribute to tissue injury during chronic inflammation. ${ }^{1-7}$ These species may arise by several mechanisms, including production by neutrophils, chondrocytes, macrophages in the pannus, ${ }^{1-57}$ and by the enzyme xanthine oxidase in the synovial membrane through the process of hypoxia reperfusion injury. ${ }^{68}$

ROS and RNS, once formed, are capable of damaging all important biomolecules. Indeed, oxidation of proteins, ${ }^{39}$ lipids, ${ }^{10}{ }^{11} \mathrm{DNA}^{1213}$ uric acid, ${ }^{14}$ polysaccharides, ${ }^{15}$ and ascorbic acid ${ }^{1617}$ has been shown to be increased in rheumatoid arthritis patients. In addition, $\mathrm{H}_{2} \mathrm{O}_{2}$ dependent inactivation of enzymes in cartilage may lead to inhibition of proteoglycan synthesis, ${ }^{1819}$ so contributing to cartilage destruction in rheumatoid arthritis by interfering with the repair of proteolytic and oxidative damage.

Elucidation of the precise role of ROS in rheumatoid arthritis has been hampered because it is difficult to measure them in vivo. ${ }^{20}$ However, $\mathrm{O}_{2}{ }^{--}, \mathrm{NO} 0^{\circ}$, and $\mathrm{H}_{2} \mathrm{O}_{2}$ cannot damage most biological macromolecules directly, and it is widely thought that they exert deleterious effects by becoming converted into the highly reactive hydroxyl radical, $\mathrm{OH}^{\circ},{ }^{121}$ which reacts at a diffusion controlled rate with almost all molecules in living cells. Although aromatic hydroxylation data consistent with increased $\mathrm{OH}^{\bullet}$ generation in rheumatoid arthritis patients have been obtained, ${ }^{22}{ }^{23}$ the origin of this $\mathrm{OH}^{*}$ cannot be determined from such whole body measurements. In the present paper we provide direct evidence for the ability of the fluid aspirated from the knee joints of rheumatoid arthritis patients to form $\mathrm{OH}^{\circ}$. In addition, the ability of whole blood to form $\mathrm{OH}^{*}$ has been demonstrated. This reactive radical was detected using two specific assays: the aromatic hydroxylation of salicylic acid ${ }^{22-24}$ and of phenylalanine. ${ }^{2526}$ Aromatic hydroxylation is a trapping assay which involves the reaction of $\mathrm{OH}^{\circ}$ with an aromatic "detector" molecule to form specific products, the production of which is diagnostic of the formation of $\mathrm{OH}^{*}$. The major products diagnostic for $\mathrm{OH}^{*}$ from the hydroxylation of salicylate are 2,3- and 2,5-dihydroxybenzoates (2,3-DHB, 2,5-DHB; fig 1), which are measured by high performance liquid chromatography (HPLC). Similarly, the aromatic amino acid L-phenylalanine is attacked by $\mathrm{OH}^{*}$ to produce three tyrosines (o-, $m$-, and $p$-tyrosine; fig 2 ). Although p-tyrosine can be produced physiologically by the activity of a 
<smiles>[R]c1cccc(O)c1O</smiles>

2,3-DHB<smiles>[R]c1ccccc1O</smiles>

Salicylic acid

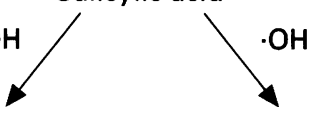<smiles>[R]c1cc(O)ccc1O</smiles>

2,5-DHB

$$
\mathrm{R}=\mathrm{CO}_{2} \mathrm{H}
$$

OH $=$ hydroxyl radical

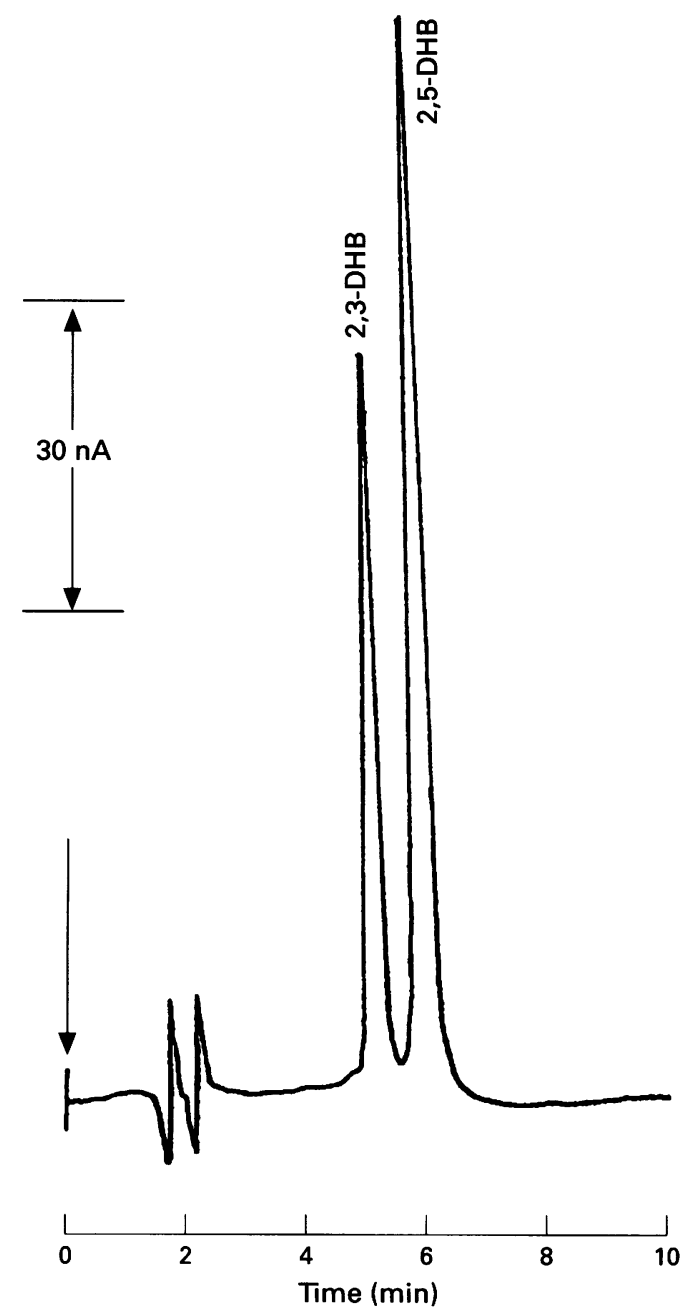

Figure 1 Diagram showing the major products of attack of hydroxyl radicals upon salicylic acid (top) and the HPLC separation achieved following a previously published procedure 33 (bottom).

phenylalanine hydroxylase enzyme, $o-$ and $m$-tyrosines do not appear to be enzyme generated products. ${ }^{2627}$

\section{Methods}

REAGENTS

Salicylic acid, L-phenylalanine, 2,3-DHB and 2,5-DHB, ortho-, meta-, and para-tyrosines, and other reagents were of the highest quality available from Sigma. Physiological saline was prepared using tablets (Dulbecco " $A$ "), and HPLC grade water was from a Maxima water purification system (ELGA Ltd, High Wycombe, Bucks, UK).

\section{PATIENTS}

Patients with rheumatoid arthritis (criteria of the American Rheumatological Association, as revised 1987) had synovial fluid aspirated from the knee joints, using the standard "no touch" technique, only when necessary for therapeutic purposes. The joint was termed "active" by definition only, that is, if an effusion was present requiring aspiration, and not in terms of Ritchie score and related indices. Synovial fluid, once aspirated, was added immediately $(1.8 \mathrm{ml})$ to either physiological saline $(0.2 \mathrm{ml})$ as a control, or to physiological saline $(0.2 \mathrm{ml})$ containing an $\mathrm{OH}^{*}$ trap (5 mM L-phenylalanine [phe] or $5 \mathrm{mM}$ salicylic acid [SAL]), or $5 \mathrm{mM}$ trap plus $\mathrm{OH}^{\circ}$ scavenger (mannitol or sodium formate) giving a final volume of $2 \mathrm{ml}$.

Blood samples were also withdrawn from the patients and treated in the same way as synovial fluid. The saline ( \pm trap) plus blood was allowed to coagulate and the serum collected. Before analysis both serum and synovial fluid samples were centrifuged at $1500 \mathrm{~g}$ for $30 \mathrm{~min}$ to remove cells and cell debris and the supernatant was collected. Samples were stored at $-20^{\circ} \mathrm{C}$ until HPLC analysis.

\section{PRE- AND POSTEXERCISE STUDY}

(HYPOXIA-REPERFUSION)

Patients were bed rested for $1 \mathrm{~h}$ before collection of their synovial fluid and blood, ${ }^{8}$ then exercised for 15 to $20 \mathrm{~min}$ before collecting a further sample. Synovial fluid and serum samples before and after exercise were collected and stored at $-20^{\circ} \mathrm{C}$ until HPLC analysis.

HPLC ANALYSES OF HYDROXYLATED COMPOUNDS Samples were thawed at room temperature and then filtered through Centrifree micropartition devices (Amicon, Gloucestershire, UK) at $2700 \mathrm{~g}$ (Heraeus Sepatech centrifuge) for $1 \mathrm{~h}$ at $20^{\circ} \mathrm{C}$. The ultrafiltrates were then analysed according to published procedures for the dihydroxybenzoates ${ }^{23}$ and tyrosines. ${ }^{26}$ Figure $2 \mathrm{~B}$ shows a representative chromatogram for tyrosines: chromatograms for dihydroxybenzoates were similar to those already published. ${ }^{23}$

\section{Results}

DETECTION OF HYDROXYL RADICAL BY AROMATIC HYDROXYLATION OF PHENYLALANINE Synovial fluid samples from 53 patients with active rheumatoid arthritis were aspirated into physiological saline (as a control) and solutions assayed for the presence of tyrosines (Tyr). No oand $m$-Tyr were detected, confirming the view that they are not normal metabolic products, that is, not formed by an enzymic pathway in humans. The concentration of $p$-Tyr was 75.2 (SD 30.7) $\mu M(n=48)$ which was not significantly different from the serum $p$-Tyr concentrations in the same patients [51.5 (21.2) $\mu \mathrm{M}, \mathrm{n}=48$ ] or from serum values of this amino acid in healthy control subjects [54.4 (21.3) $\mu \mathrm{M}, \mathrm{n}=20$ ]. The serum and synovial fluid Phe concentrations were less 
Table 1 Products of hydroxylation of Phe (o-, $m$-and p-tyrosines) measured in body fluids of rheumatoid patients and healthy controls added to solutions containing $P$ he as a detector for hydroxyl radicals

\begin{tabular}{|c|c|c|c|c|c|c|}
\hline \multirow[b]{3}{*}{ Patients } & \multicolumn{6}{|l|}{ Tyrosines $(\mu M)$} \\
\hline & \multicolumn{3}{|l|}{ In synovial fluid } & \multicolumn{3}{|c|}{ In serum after addition of whole blood } \\
\hline & $o-$ & $m-$ & $p-$ & $0-$ & $m-$ & $p-$ \\
\hline $\begin{array}{l}\text { Healthy controls }(n=20) \\
\text { RA }(n=53)\end{array}$ & $1.6(2.2) \quad(n=50)$ & $\begin{array}{l}\text { Not available } \\
1.5(2.1) \quad(n=49)\end{array}$ & $72.5(29.7) \quad(n=50)$ & $\begin{array}{l}\text { ND } \\
1.8(2.5) \quad(n=50)\end{array}$ & $\begin{array}{l}\text { ND } \\
1.8(2.3) \quad(n=51)\end{array}$ & $\begin{array}{lll}63.3 & (23.7) & (\mathrm{n}=20) \\
50.5 & (20.1) & (\mathrm{n}=52)\end{array}$ \\
\hline
\end{tabular}

All values given here are mean (SD) with the number of subjects in brackets. Statistics include zero (ND) values.

ND, not detected.

Levels of $o-, m$ - and $p$-tyr in serum and SF are not significantly different.

$\star$ Synovial fluid was not available from normal controls.

than $100 \mu \mathrm{M}$, a level below that needed to trap any $\mathrm{OH}^{\circ}$. However, when synovial fluid was aspirated and immediately added to a solution containing a high concentration of Phe $(5 \mathrm{mM})$, $o$ - and $m$-Tyr were formed (table 1; fig 2B) but concentrations of $p$-tyrosine were essentially identical to the saline controls (table 1). A similar phenomenon was seen when blood was added to the Phe solution and tyrosines then measured in the serum after clotting. Blood from healthy human controls never gave any evidence of $o$ - or $m$-tyrosine formation.
A<smiles>[R]c1ccccc1</smiles>

Phenylalanine<smiles>[R]c1ccccc1O</smiles><smiles>CC(C)O</smiles><smiles>[R]c1cccc(O)c1</smiles>

o-Tyrosine m-Tyrosine H<smiles>[CH]C</smiles><smiles>[R]c1ccc(O)cc1</smiles>

p-Tyrosine $\mathrm{R}=\mathrm{CH}_{2} \mathrm{CH}\left(\mathrm{NH}_{2}\right) \mathrm{CO}_{2} \mathrm{H}$ $. \mathrm{OH}=$ hydroxyl radical

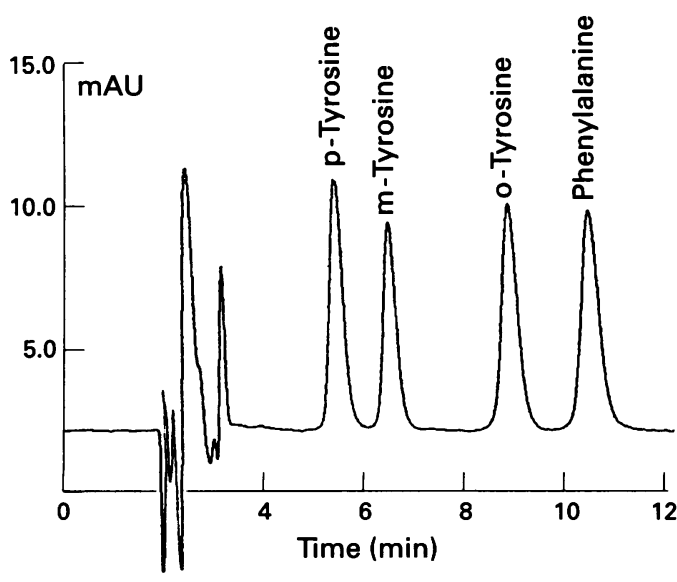

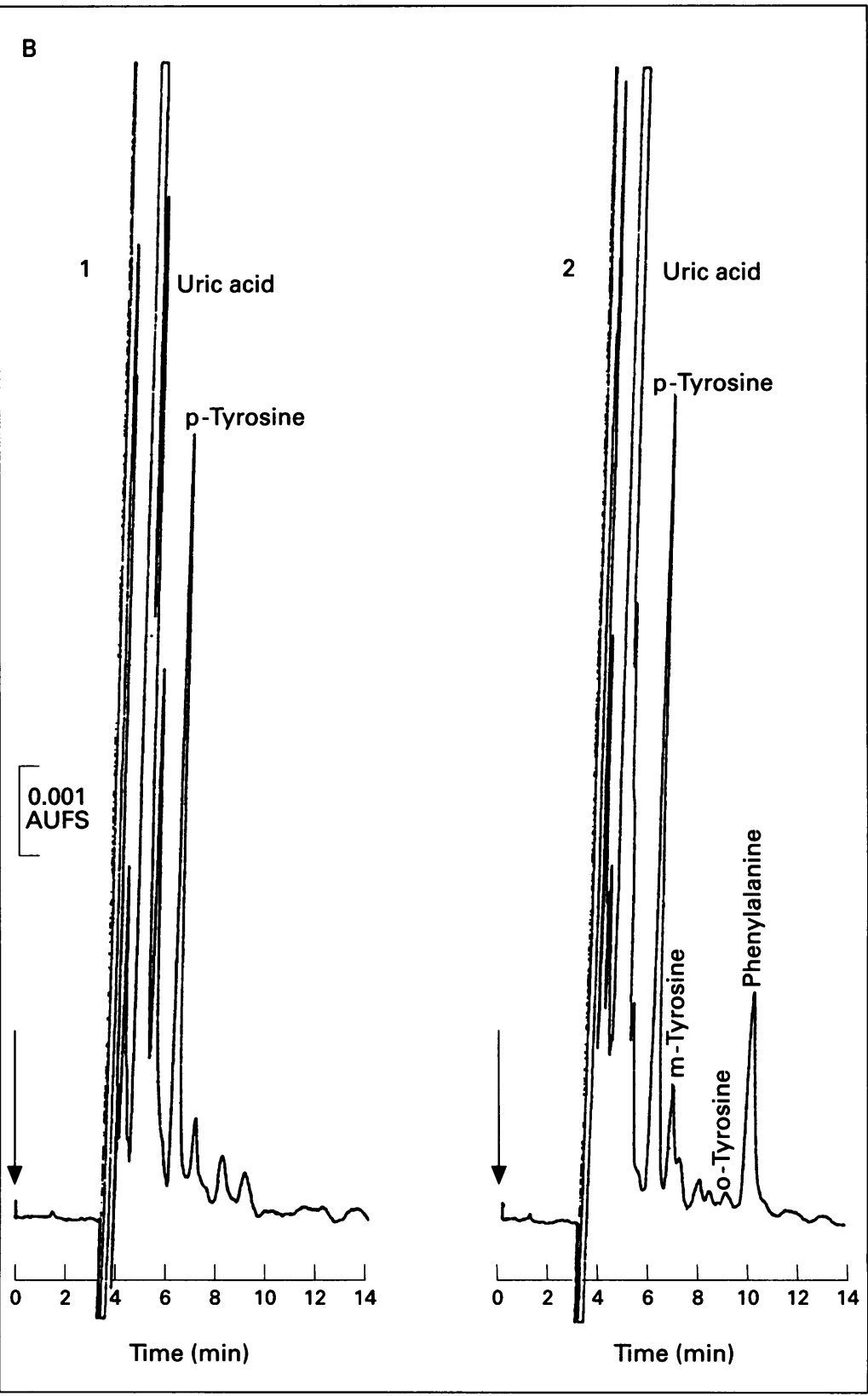

Figure 2 (A) Diagram showing the products of attack of hydroxyl radical upon phenylalanine (top) and the HPLC separation achieved following a previously published procedure ${ }^{26}$ (bottom). (B) A representative chromatogram showing HPLC analysis of tyrosines after addition of synovial fluid to phenylalanine (2) or to saline (1). 
Table 2 Biochemical variables and tyrosines measured in biological fluids of three rheumatoid patients examined more than once

\begin{tabular}{|c|c|c|c|c|c|c|c|c|c|}
\hline \multirow{3}{*}{ Subject } & \multirow{3}{*}{ Date seen } & \multirow{2}{*}{\multicolumn{2}{|c|}{ Biochemical variable }} & \multicolumn{6}{|c|}{ Tyrosines $-\mu M$} \\
\hline & & & & \multicolumn{3}{|c|}{ In synovial fluid } & \multicolumn{3}{|c|}{ In serum } \\
\hline & & $E S R m m h^{-1}$ & $C R P m g t^{1}$ & $o-$ & $m-$ & $p-$ & $o-$ & $m-$ & $p-$ \\
\hline \multirow[t]{3}{*}{ Patient 1} & April '92 & 53.0 & 7.92 & 2.0 & 2.0 & 78.0 & 2.0 & 1.0 & 73.0 \\
\hline & May '92 & 76.0 & 5.66 & 1.0 & 2.0 & 61.0 & 1.0 & 2.0 & 54.0 \\
\hline & June '94 & Not available & Not available & 2.7 & 1.6 & 108.0 & 3.0 & 2.0 & 110.0 \\
\hline \multirow[t]{2}{*}{ Patient 2} & April '92 & 56.0 & 2.52 & 4.0 & 1.0 & 84.0 & 2.0 & 1.0 & 65.0 \\
\hline & June '93 & 80.0 & Not available & 0.5 & 0.5 & 84.0 & 0.2 & 0.3 & 65.0 \\
\hline \multirow[t]{2}{*}{ Patient 3} & June '92 & 100.0 & 9.17 & 0.9 & 3.5 & 66.5 & 1.0 & 2.5 & 60.0 \\
\hline & Nov'92 & 86.0 & 3.61 & 1.0 & 2.5 & 60.0 & 2.6 & 0.8 & 39.0 \\
\hline
\end{tabular}

Note, all other patients were sampled only once in this study.

Not every rheumatoid arthritis patient examined produced fluids that caused conversion of Phe to products diagnostic of $\mathrm{OH}^{\circ}$ attack. Of the 53 patients examined, 17 did not (these negative values were included in calculating the mean and standard deviations in table 1 ). No significant correlation was found between laboratory indices of inflammation [erythrocyte sedimentation rate (ESR); $C$ reactive protein in serum or synovial fluid] and whether or not the fluids showed evidence of $\mathrm{OH}^{\circ}$. ESR values ranged from 6 to $100 \mathrm{~mm} / \mathrm{h}$ [mean 58.7 (25.9), $\mathrm{mm} / \mathrm{h}, \mathrm{n}=39$ ]; $\mathrm{C}$ reactive protein estimations in serum ranged from 0.1 to $89.8 \mathrm{mg}$ litre $^{-1}$ [mean 15.4 (24.9) $\mathrm{mg} \mathrm{litre}^{-1}(\mathrm{n}=28]$.

REPRODUCIBILITY OF THE DETECTION OF OH FROM PATIENTS USING PHENYLALANINE

During the course of this study we were able to obtain samples from three patients at different times. Table 2 shows the results. Even though $C$ reactive protein, $E S R$, and clinical indices of disease activity were different at each time of sampling, $\mathrm{OH}^{*}$ was always detected.

EFFECT OF HYPOXIA-REOXYGENATION

It has been suggested that exercise of the inflamed rheumatoid joint creates a hypoxiareperfusion phenomenon that induces and exacerbates free radical damage. ${ }^{8}$ The generation of $o$ - and $m$-tyrosines was therefore investigated under conditions of hypoxia and hypoxia-reoxygenation. The levels of $p$-tyrosine from rheumatoid arthritis fluids collected in saline as a control were not significantly different: synovial fluid before hypoxiareoxygenation $=75.2(30.7) \mu \mathrm{M}, \mathrm{n}=48$; after hypoxia-reoxygenation $=72.2(40.2) \mu \mathrm{M}, \mathrm{n}=$ 22; serum before hypoxia-reoxygenation $=$ 51.5 (21.2) $\mu \mathrm{M}, \mathrm{n}=49$; after hypoxiareoxygenation $=43.5$ (22.4) $\mu \mathrm{M}, \mathrm{n}=23$. Orthoand meta-tyrosines were never observed.

Table 3 shows the results of measurements on the same fluids collected into $5 \mathrm{mM}$ phenylalanine. There was a tendency for levels of

Table 3 Products of hydroxylation of Phe (o-, m-, p-tyrosines) measured in body fluids (collected in $5 \mathrm{mM}$ Phe) of rheumatoid patients following in vivo hypoxia-reoxygenation

\begin{tabular}{llllll}
\hline RA fluid & $o-T y r-\mu M$ & $m-T y r-\mu M$ & $p-T y r-\mu M$ \\
\hline SF $_{\mathrm{PRE}}$ & $1.6(2.2)(\mathrm{n}=50)$ & $1.5(2.1)(\mathrm{n}=49)$ & $72.5(29.7)(\mathrm{n}=50)$ \\
SF $_{\mathrm{POST}}$ & $2.5(3.7)(\mathrm{n}=27)$ & $2.0(2.8)(\mathrm{n}=28)$ & $74.6(64.6)(\mathrm{n}=27)$ \\
$\mathrm{S}_{\mathrm{PRE}}$ & $1.8(2.5)(\mathrm{n}=50)$ & $1.8(2.3)(\mathrm{n}=51)$ & $50.5(20.1)(\mathrm{n}=52)$ \\
S $_{\text {POST }}$ & $2.4(3.2)(\mathrm{n}=27)$ & $3.2(4.1)(\mathrm{n}=26)$ & $63.3(23.7)(\mathrm{n}=20)$ \\
\hline
\end{tabular}

All values are mean (SD) including ND as a zero value.

$\mathrm{SF}$, synovial fluid; $\mathrm{S}$, serum. $o$ - and $m$-Tyr to increase, but this was not statistically significant. Levels of $p$-Tyr were similar.

EFFECT OF CENTRIFUGATION

If synovial fluid was centrifuged $(1500 \mathrm{~g}$ for 30 $\mathrm{min}$ ) to remove cells before it was added to $5 \mathrm{mM}$ Phe, the formation of $o$ - and $m$-tyrosines was no longer observed (table 4 ).

CONFIRMATION OF HYDROXYL RADICAL FORMATION BY USING A DIFFERENT DETECTOR MOLECULE, THE AROMATIC HYDROXYLATION OF SALICYLATE

We attempted to trap $\mathrm{OH}^{*}$ from the fluids of 22 rheumatoid arthritis patients using $5 \mathrm{mM}$ salicylic acid as an alternative trap and the results are shown in table 5 . When synovial fluid was collected in saline, no 2,3-DHB was detected and $0.018(0.03) \mu \mathrm{M}(\mathrm{n}=12)$ of $2,5-\mathrm{DHB}$ found (these statistics include "not detected" levels taken as zero). This may be because traces of 2,5-DHB can come from the diet, for example plant materials and ingested drugs containing aspirin or salicylate (five patients were taking $75-100 \mathrm{mg}$ aspirin daily). For comparison blood added to solutions containing saline gave serum that contained no detectable 2,3-DHB and $0.024(0.051) \mu \mathrm{M}(\mathrm{n}=16)$ of 2,5 DHB. When synovial fluid was aspirated into salicylate ( $5 \mathrm{mM}), 2,3-$ and $2,5-\mathrm{DHB}$ were formed (table 5). These 22 patients had also been tested using Phe as a trap, and again the same 18 showed evidence of $\mathrm{OH}^{*}$ generation ( $o$ - and $m$-Tyr formation; see above).

FURTHER EVIDENCE FOR HYDROXYL RADICAL FORMATION: THE EFFECT OF SCAVENGERS Mannitol and formate are specific scavengers of $\mathrm{OH}^{\cdot}{ }^{28}$ Their inclusion in the sampling tubes with salicylate caused inhibition of the formation of 2,3- and 2,5-DHB (table 5), as would be expected if generation of these products is due to $\mathrm{OH}^{\circ}$.

Table 4 Synovial fluid collected in $5 \mathrm{mM}$ Phe, freshly aspirated or first centrifuged to remove the cells. Data from two representative patients are shown

\begin{tabular}{llllr}
\hline & & \multicolumn{3}{c}{ Tyrosines $-\mu M$} \\
\cline { 3 - 5 } Subject & Fluid & $o-$ & $m-$ & \multicolumn{1}{c}{$p$ - } \\
\hline Patient 1 & SF & 1.0 & 0.5 & 55.5 \\
& Spun SF & ND & ND & 46.0 \\
Patient 2 & SF & 3.5 & 1.0 & 127.5 \\
& Spun SF & ND & ND & 97.5 \\
\hline
\end{tabular}

SF, synovial fluid. 
Table 5 Products of hydroxylation of salicytate (2,3- and 2,5-dihydroxybenzoate) measured in body fluids of rheumatoid patients. The effects of $\mathrm{OH}$ scavengers (mannitol and formate). Values are mean (SD)

\begin{tabular}{lll}
\hline Fluid & $2,3-D H B \mu M$ & $2,5-D H B \mu M$ \\
\hline SF & $0.38(0.69)(n=12)$ & $0.42(0.61) \quad(n=13)$ \\
SF + mannitol $(100 \mathrm{mM})$ & $0.16(0.08)(\mathrm{n}=6)$ & $0.21(0.08)(\mathrm{n}=6)$ \\
SF + formate $(100 \mathrm{mM})$ & $0.03(\mathrm{n}=1)$ & $0.15(\mathrm{n}=1)$ \\
& $0.11(\mathrm{n}=1)$ & $0.16(\mathrm{n}=1)$ \\
S & $0.31(0.21)(\mathrm{n}=16)$ & $0.79(0.96)(\mathrm{n}=16)$ \\
S + mannitol $(100 \mathrm{mM})$ & $0.13(0.15)(\mathrm{n}=11)$ & $0.53(0.71)(\mathrm{n}=11)$ \\
S + formate $(100 \mathrm{mM})$ & $0.07(0.03)(\mathrm{n}=5)$ & $0.19(0.14)(\mathrm{n}=5)$ \\
\hline
\end{tabular}

SF, synovial fluid; $\mathrm{S}$, serum (obtained after addition of blood to salicylate solution, then allowing to clot).

\section{Discussion}

The results in the present paper show that aspirated knee joint fluid from patients with active rheumatoid arthritis can make the highly damaging $\mathrm{OH}^{*}$ radical, as demonstrated using specific techniques of aromatic hydroxylation of two different detector molecules and the effects of $\mathrm{OH}^{*}$ scavengers. The ability of synovial fluid to make $\mathrm{OH}^{*}$ has long been suspected, ${ }^{1-3}$ for example on the basis of detection of hydroxylation products of salicylate in vivo, ${ }^{22} 23$ but is here shown directly. The $\mathrm{OH}^{\circ}$ could be formed by at least three mechanisms.

(1) In the presence of "catalytic" iron ions, $\mathrm{O}_{2} \cdot-$ and $\mathrm{H}_{2} \mathrm{O}_{2}$ may be converted to $\mathrm{OH}^{\circ}$ by a metal ion catalysed Haber-Weiss reaction. ${ }^{21}$ The necessary iron could arise from $\mathrm{H}_{2} \mathrm{O}_{2}$ dependent degradation of haemoglobin, ${ }^{2930}$ perhaps released by traumatic microbleeding in the joint. Another source could be $\mathrm{O}_{2}{ }^{-}$ dependent release of iron from synovial fluid ferritin. ${ }^{31}$

(2) The interaction of $\mathrm{NO}^{*}$ and $\mathrm{O}_{2}{ }^{--}$forms the cytotoxic product peroxynitrite, $\mathrm{ONOO}^{-}$ At physiological $\mathrm{pH}$, $\mathrm{ONOO}^{-}$converts to its protonated form - peroxynitrous acid, $\mathrm{ONOOH}$ - which decays to generate multiple toxic products, believed to include nitronium ion $\left(\mathrm{NO}_{2}{ }^{+}\right)$, nitrogen dioxide radical $\left(\mathrm{NO}_{2}{ }^{\circ}\right)$, and a species resembling $\mathrm{OH}^{\cdot} .^{32-35}$ Production of not only $\mathrm{O}_{2}{ }^{--}$but also $\mathrm{NO}^{\circ}$ appears to be increased in rheumatoid arthritis patients, measured in terms of increased nitrite levels in serum and synovial fluid from these patients. There is also an increase in nitrotyrosine levels, consistent with $\mathrm{ONOO}^{-}$formation in vivo. ${ }^{36}$

(3) Activated neutrophils secrete the enzyme myeloperoxidase which uses $\mathrm{H}_{2} \mathrm{O}_{2}$ produced from $\mathrm{O}_{2}{ }^{--}$to generate the powerful anti-bacterial agent hypochlorous acid, $\mathrm{HOCl}$. In a pathway apparently independent of metal ions, $\mathrm{HOCl}$ reacts with $\mathrm{O}_{2}{ }^{-1}$ to generate $\mathrm{OH}^{\circ} .^{37}$ A second key point from our results is the ability of whole blood to cause $\mathrm{OH}^{\circ}$ formation in some rheumatoid arthritis patients, but not in others or in normal controls. Plasma from healthy subjects is known not to be capable of catalysing $\mathrm{OH}^{\circ}$ formation, and "catalytic" iron ions are not present in plasma even in rheumatoid arthritis patients. ${ }^{43}$ Indeed, prior centrifugation of the blood or allowing it to clot and then adding serum or plasma to salicylate or phenylalanine produced no detectable $\mathrm{OH}^{\circ}$. The same was true if synovial fluid was spun before addition (table 4). These data suggest that cells are involved in the $\mathrm{OH}^{*}$ generation, perhaps primed/activated neutrophils, which may occur not only in synovial fluid but also in the systemic circulation in rheumatoid arthritis, given the extensive overproduction of various cytokines. ${ }^{45}$ However, this conclusion is tentative, since it is possible that during the centrifugation time the fluids lose their ability to generate $\mathrm{OH}^{*}$. There was no significant correlation between white cell count and ability of blood to cause $\mathrm{OH}^{*}$ formation (data not shown).

A third key point from our results is the variability in $\mathrm{OH}^{\circ}$ formation between different rheumatoid arthritis patients, and it seems that factors other than the extent of ongoing inflammation affect the levels of $\mathrm{OH}^{\circ}$ generation. Factors that could account for this include variations in the availability of iron catalytic for $\mathrm{OH}^{\circ}$ generation in synovial fluid, ${ }^{38}$ variations in endogenous antioxidant defences, ${ }^{39}$ and the effects of drug treatment. ${ }^{40}$ Some drugs may decrease oxidative damage (reviewed in ') whereas others may actually increase it, despite being anti-inflammatory overall. $^{40-42}$ These points will be explored in future studies.

The techniques of aromatic hydroxylation used in our study are well established. Thus, for example, salicylic acid has been used to show raised levels of 2,3- and 2,5-DHB in rheumatoid arthritis patients taking aspirin, ${ }^{223}$ and phenylalanine has been used to trap $\mathrm{OH}^{\circ}$ produced in isolated cells, ${ }^{25}$ in blood from some premature babies, ${ }^{26}$ and from reperfused heart in situ. ${ }^{27}$

It has been proposed that, in the early stages of inflammation, exercise promotes cycles of hypoxia-reoxygenation which can lead to the production of oxidising species that cause further damage to the joint. ${ }^{8}$ Our results are consistent with this concept in that they suggest a rise in $\mathrm{OH}^{\circ}$ production, although statistical significance was not achieved.

In conclusion, we have shown that synovial fluid and blood from certain rheumatoid arthritis patients have the ability to generate $\mathrm{OH}^{*}$. It is likely that this highly reactive radical species contributes to injury at sites of chronic inflammation and may also contribute to systemic damage, although its precise pathological role remains to be ascertained.

We are very grateful to the Arthritis and Rheumatism Council for research support, and to Drs S Chirico and R Williams for assisting at the beginning of this study.

1 Halliwell B. Oxygen radicals, nitric oxide and human inflammatory joint disease. Ann Rheum Dis 1995;54:505-10. 2 Edmonds SE, Blake DR, Morris CJ, Winyard PG. An maginative approach to synovitis - the role of hypoxic reperfusion damage in arthritis. $\mathcal{F}$ Rheumatol 1993;20:26-31.

3 Lunec J, Blake DR, McCleary SJ, Brailsford S, Bacon PA. Self-perpetuating mechanisms of immunoglobulin G aggregation in rheumatoid inflammation. F Clin Invest 1985;76:2084-90.

4 Eggleton P, Wang L, Perihallow J, Crawford N, Brown KA. Difference in oxidative response of subpopulations of neutrophils from healthy subjects and patients with rheumatoid arthritis. Ann Rheum Dis 1995;54:916-23.

5 Robinson J, Watson F, Bucknall RC, Edwards SW. Activation of neutrophil reactive-oxidant production by Activation of neutrophil reactive-oxidant production by
synovial fluid from patients with inflammatory joint synovial fluid from patients with
disease. Biochem $₹$ 1992;286:345-51.

6 Stevens CR, Benboubetra M, Harrison R, Sahinoglu T, Smith EC, Blake DR. Localization of xanthine oxidase to synovial endothelium. Ann Rheum Dis 1991;50:760-62. 
7 Farrell AJ, Blake DR, Palmer RMJ, Moncada S. Increased concentrations of nitrite in synovial fluid and serum samples suggest increased nitric oxide synthesis in rheumatic diseases. Ann Rheum Dis 1992;51:1219-22.

8 Blake DR, Merry P, Unsworth J, Kidd B, Ballard R, Morris $\mathrm{CJ}$, et al. Hypoxic-reperfusion injury in the inflamed human joint. Lancet 1989;334:289-93.

9 Griffiths HR, Lunec J. Effects of reactive oxygen species on immunoglobulin G function. Mol Aspects Med 1991; 12:107-19.

10 Rowley DA, Gutteridge JMC, Blake D, Farr M, Halliwell B. Lipid peroxidation in rheumatoid arthritis: thiobarbituricreactive material and catalytic iron salts in synovial fluid from rheumatoid patients. Clin Sci 1984;66:691-95.

11 Humad S, Zarling E, Clapper M, Skosey JK. Breath pentane excretion as marker of disease activity in rheumatoid arthritis. Free Radic Res Commun 1988;5:101-6.

12 Bashir S, Harris G, Denman MA, Blake DR, Winyard PG. Oxidative DNA damage and cellular sensitivity to oxidative stress in human autoimmune diseases. Ann Rheum Dis 1993;52:659-66.

13 Lunec J, Herbert K, Blount S, Griffiths HR, Emery P. 8-Hydroxydeoxyguanosine: a marker of DNA damage in systemic lupus erythematosus. FEBS Lett 1994;348:131-8.

14 Grootveld M, Halliwell B. Measurement of allantoin and uric acid in human body fluids. A potential index of free uric acid in human body fluids. A potential index of

15 Grootveld M, Henderson EB, Farrell A, Blake DR, Parkes HG, Haycock P. Oxidative damage to hyaluronate and glucose in synovial fluid during exercise of the inflamed rheumatoid joint. Biochem $\mathcal{F}$ 1991;272:459-67.

16 Lunec J, Blake DR. The determination of dehydroascorbic acid in the serum and synovial fluid of patients with rheumatoid arthritis. Free Radic Res Commun 1985;1:32-9.

17 Situnayake RD, Thurnham DI, Kootathep S, Chirico S, Lunec J, Davis $M$, et al. Chain breaking antioxidant status in rheumatoid arthritis: clinical and laboratory correlates. Ann Rheum Dis 1991:50:81-6.

18 Bates EJ, Johnson CC, Lowther DA. Inhibition of proteoglycan synthesis by hydrogen peroxide in cultured proteoglycan synthesis by hydrogen peroxide in cultured
bovine articular cartilage. Biochim Biophys Acta 1985; 838:221-8.

19 Schalkwijk J, van den Berg WB, Van de Putte LBA, Joosten LAB. An experimental model for hydrogen peroxideinduced tissue damage. Effect of a single inflammatory mediator on (peri) articular tissues. Arthritis Rheum 1986; 29:532-8.

20 Halliwell B.Oxidative stress, nutrition and health.Experimental strategies for optimisation of nutritional antioxident intake in humans. Free Radic Res 1996;25:57-74.

21 Halliwell B. Superoxide-dependent formation of hydroxyl radicals in the presence of iron salts. Its role in degradation of hyaluronic acid by a superoxide-generating system. FEBS Lett 1978;96:238-42.

22 Cleland LG, Lowthian PJ, Imhof,D, Bochner F, Betts WH, O'Callaghan J. Plasma and synovial fluid gentisate in
patients receiving salicylate therapy. $f$ Rheumatol 1985 ; patients

23 Grootveld $M$, Halliwell B. Aromatic hydroxylation as a potential measure of hydroxyl radical formation in vivo. Identification of hydroxylated derivatives of salicylate in human body fluids. Biochem $\mathcal{f}$ 1986;237:499-504.

24 Ingelman-Sundberg $M$, Kaur $H$, Terelius Y, Persson JO, Halliwell B. Hydroxylation of salicylate by microsomal fractions and cytochrome P-450. Biochem f 1991; 276:753-7.
25 Kaur H, Fagerheim I, Grootveld M, Puppo A, Halliwell B Aromatic hydroxylation of phenylalanine as an assay fo hydroxyl radicals. Anal Biochem 1988;172:360-7.

26 Kaur H, Halliwell B. Aromatic hydroxylation of phenylalanine as an assay for hydroxyl radicals. Anal Biochem 1994;220:11-15.

27 Sun JZ, Kaur H, Halliwell B, Li XY, Bolli R. Use of aromatic hydroxylation of phenylalanine to measure production of hydroxyl radicals after myocardial ischemia in intact dogs. Circ Res 1993;73:534-49.

28 Halliwell B, Gutteridge JMC. Free radicals in biology and medicine, 2nd ed. Oxford: Calrendo Press, 1989.

29 Gutteridge JMC. Iron promoters of the Fenton reaction and lipid peroxidation can be released from haemoglobin by peroxides. FEBS Lett 1986;201:291-5.

30 Puppo A, Halliwell B. Formation of hydroxyl radicals from hydrogen peroxide in the presence of iron. Is haemoglobin a biological Fenton catalyst? Biochem $f$ 1988;249:185-90.

31 Biemond P, Swaak AJG, Van Eijk HG, Koster JF Intra-articular ferritin-bound iron in rheumatoid arthritis. A factor that increases oxygen free radical-induced tissue destruction. Arthritis Rheum 1986;29:1187-93.

32 Beckman TW, Chen J, Marshall PA, Freeman BA. Apparent hydroxyl radical production by peroxynitrite: implications for endothelial injury from nitric oxide and superoxide. Proc Natl Acad Sci USA 1990;87:1620-4.

33 Van der Vliet A, O'Neill CA, Halliwell B, Cross CE, Kaur $H$. Aromatic hydroxylation and nitration of phenylalanine and tyrosine by peroxynitrite. FEBS Lett 1994:339:89-92.

34 Pou S, Nguyen SY, Gladwell T, Rosen G. Does peroxynitrite generate hydroxyl radical? Biochem Biophys Acta 1995; 1244:62-8.

35 Hogg N, Darley-Usmar VM, Wilson MT, Moncada S. Production of hydroxyl radicals from the simultaneous generation of $\mathrm{O}_{2}{ }^{--}$and nitric oxide. Biochem $f$ 1992; 281:419-24.

36 Kaur H, Halliwell B. Evidence for nitric oxide mediated oxidative damage in chronic inflammation. FEBS Let 1994;350:9-12.

37 Candeias LP, Patel KB, Stratford MRL, Wardman P. Fre hydroxyl radicals are formed on reaction between the neutrophil-derived species superoxide anion and hypochlorous acid. FEBS Lett 1993;333:151-3.

38 Gutteridge JMC. Bleomycin-detectable iron in knee-joint synovial fluid from arthritic patients and its relationship to the extracellular antioxidant activities of caeruloplasmin transferrin, and lactoferrin. Biochem $¥$ 1987;245:415-21.

39 Blake DR, Allen RE, Lunec J. Free radicals in biological systems - a review orientated to inflammatory processes.

40 Halliwell B, Evans PJ, Kaur H, Chirico S. Drug-derived radicals: mediators of the side effects of anti-inflammatory drugs? Ann Rheum Dis 1992;51:1261-3.

41 Evans PI, Cecchini R, Halliwell B. Oxidative damage to lipids and $\alpha-1$-antiproteinase by phenylbutazone in the presence of haem proteins. Protection by Biochem Pharmacol 1992;44:981-4.

42 Aruoma OI, Halliwell B, Butler J, Hoey BM. Apparent inactivation of $\alpha_{1}$-antiproteinase by sulphur-containing radicals derived from penicillamine. Biochem Pharmacol 1989;38:4353-57.

43 Halliwell B, Gutteridge JMC. The antioxidants of huma extracellular fluids. Arch Biochem Biophys 1990;280:1-8. 